\title{
O contexto de aplicação e o sistema de enunciados e teses: implicações na relação entre as filiações biológica e afetiva
}

\author{
The context of application and the system of statements and thesis: implications in the \\ relationship between biological and affective parenthood
}

\author{
Elmer da Silva Marques* \\ Juliane Gloria Sulzbach**
}

\section{REFERÊNCIA}

MARQUES, Elmer da Silva; SULZBACH, Juliane Gloria. O contexto de aplicação e o sistema de enunciados e teses: implicações na relação entre as filiações biológica e afetiva. Revista da Faculdade de Direito da UFRGS, Porto Alegre, n. 47, p. 221-240, dez. 2021. DOI: https://doi.org/10.22456/0104-6594.108557.

\begin{abstract}
RESUMO
O presente artigo tem por objeto a análise da decisão proferida pelo Superior Tribunal de Justiça (STJ) no Recurso Especial n ${ }^{\circ} 1.784 .726 /$ SP. No julgamento, o STJ reafirmou entendimento de que não há, em tese, preponderância da filiação socioafetiva sobre a filiação biológica. A prevalência de uma sobre a outra ou a possibilidade de coexistência de ambas depende do caso concreto. Não se pode falar na existência de uma "preponderância da filiação socioafetiva sobre a filiação biológica". A análise é feita tendo como objetivo demonstrar como os textos jurídicos descontextualizados na prática jurídica brasileira influenciam na tomada de decisões posteriores, prejudicando o sistema de precedentes judiciais. A utilização de "teses", ementas e enunciados abstratos e desconectados dos fatos que fornecem um contexto de aplicação levam a uma série de problemas. Este complexo de aplicações incorretas que condicionam o resultado deve ser afastado, fundada na análise do quadro fático como condição sine qua non para compreensão e interpretação-aplicação dos textos normativos. Metodologicamente, o presente estudo funda-se em um modelo descritivo, no que diz respeito à exposição sistemática dos fundamentos teóricos que estabelecem a moldura teórica que entendemos adequada para o endereçamento da problemática, e na construção de um modelo normativo, pelo qual propõe-se a adoção de uma prática jurídica fundada na análise do contexto fático como condição sine qua non para compreensão e interpretação-aplicação dos textos normativos.
\end{abstract}

\section{PALAVRAS-CHAVE}

Parentalidade. Epistemologia e Hermenêutica jurídicas. Contexto de aplicação.

\begin{abstract}
The purpose of this article is to analyze the decision issued by the Brazilian Superior Court of Justice (STJ) in the Recurso Especial $n^{o}$. 1.784.726/SP. At the trial, the STJ reaffirmed its understanding that there is not, in theory, a preponderance of socio-affective parenthood over biological parenthood. The prevalence of one over the other or the possibility of coexistence of both depends on the specific case. One cannot speak of the existence of a "preponderance of socio-affective parenthood over biological parenthood". The analysis is carried out with the objective of demonstrating how the decontextualized legal texts in Brazilian legal practice influence later decision making, spoiling the system of judicial precedents. The use of abstract "theses", headnotes and statements disconnected from the facts that provide an application context lead to a series of problems. This complex of incorrect applications that condition the result must be removed, based on the analysis of the factual framework as a sine qua non condition for the understanding and interpretation-application of the normative
\end{abstract}

*Doutor em Direito pela Universidade Federal do Paraná. Mestre em Direito pela Universidade Estadual de Londrina. Bacharel em Direito pela Universidade Estadual de Maringá. Professor adjunto do curso de Direito da Universidade Estadual do Oeste do Paraná - campus de Francisco Beltrão.

**Acadêmica do curso de graduação em Direito da Universidade Estadual do Oeste do Paraná - campus de Francisco Beltrão. Integrante do projeto de iniciação científica voluntária denominado "Precedentes judiciais, tribunais superiores e reclamação constitucional", sob orientação do primeiro autor, vinculado ao Grupo de Pesquisa "Constitucionalismo e Estado Contemporâneo". 
texts. Methodologically, this study is based on a descriptive model, with regard to the systematic exposition of the theoretical foundations that establish the theoretical framework that we believe is adequate for addressing the problem, and on the construction of a normative model, by which it is proposed the adoption of a legal practice based on the analysis of the factual context as a sine qua non for the understanding and interpretationapplication of normative texts..

\section{KEYWORDS \\ Parenthood. Legal Epistemology and Hermeneutic. Context of application.}

\section{SUMÁRIO}

1. Introdução. 2. Filiação socioafetiva versus filiação biológica. 3. Análise da decisão proferida no Recurso Especial n. 1.784.726/SP. 4. Vagueza e descontextualização das teses, dos enunciados, das ementas e das súmulas.

5. Conclusão. Referências Bibliográficas. Dados da publicação.

\section{INTRODUÇÃ̃O}

O presente estudo tem por objetivo demonstrar a importância do contexto de aplicação para a compreensão do texto legal, incluído, nesta expressão, o texto da lei lato sensu e o texto das decisões judiciais. Parte do reconhecimento de que vige, no Brasil, uma prática jurídica fundada na utilização de textos legais descontextualizados: os operadores do Direito utilizamse de enunciados de leis, de ementas, de teses e de súmulas ${ }^{1}$ sem que a compreensão de seu significado decorra da análise do contexto no qual foram ou deverão ser aplicados.

De forma a ilustrar alguns dos problemas decorrentes daquela prática, optou-se por escolher uma temática relativamente recente: a multiparentalidade e os possíveis confrontos existentes entre a filiação socioafetiva e a filiação biológica. ${ }^{2}$ A decisão escolhida é a que foi proferida pelo Superior Tribunal de Justiça (STJ) no Recurso Especial $n^{\circ} 1.784 .726 / S P$, tendo por relator o Ministro Luís Felipe Salomão.

Por esta decisão, o STJ reformou acórdão proferido pelo Tribunal de Justiça do Estado de São Paulo que decidiu que, muito embora o exame de DNA tenha provado a filiação consanguínea da autora que postulava o reconhecimento de paternidade, esta filiação biológica somente poderia ser declarada judicialmente uma vez que ficasse provada a inexistência de posse de estado de filho que gerasse filiação socioafetiva. Em outras palavras, se houvesse o

\footnotetext{
${ }^{1}$ Por "Enunciados" (de leis, de ementas, de teses e de súmulas) entendemos os textos, sem referência a conteúdo fático, que constituem as leis, as ementas, as teses proferidas pelos tribunais superiores e as súmulas. O cerne deste estudo é justamente demonstrar a importância do contexto fático como requisito para a compreensão e aplicação dos enunciados.

2 Para fins deste estudo, entendemos "filiação biológica" como aquela que decorre da transmissão genética decorrente dos atos de reprodução natural ou assistida; "filiação socioafetiva" aquela que decorre do estabelecimento de vínculos afetivos duradouros, reconhecendo as pessoas envolvidas mutuamente como pai/mãe e filho/a, sem a existência de compartilhamento do material genético entre eles. Por "multiparentalidade" ou "pluriparentalidade" entende-se o fato de uma mesma pessoal possuir mais de um pai e/ou mais de uma mãe, como por exemplo, um filho que possui, formalmente, reconhecido, um pai biológico e um pai socioafetivo.
} 
reconhecimento de filiação afetiva, esta impediria o reconhecimento da filiação biológica, mesmo estando provada por exame de DNA.

No julgamento da decisão objeto do presente estudo, o STJ reformou o entendimento do Tribunal bandeirante para deixar claro que "a tese segundo a qual a paternidade socioafetiva sempre prevalece sobre a biológica deve ser analisada com bastante ponderação, a depender sempre do exame do caso concreto". E é exatamente este o objeto do presente estudo: a utilização de "teses", “enunciados", "ementas", toda sorte de textos legais que são aplicados de forma descontextualizada e que levou o tribunal paulista a aplicar, data venia, equivocadamente uma "tese" a uma situação de fato diferente do conjunto fático que originou a própria tese.

O presente estudo foi estruturado da seguinte forma: no primeiro capítulo, uma pequena exposição sobre a filiação biológica, a filiação socioafetiva e a posse de estado de filho; no segundo capítulo, analisa-se o julgamento proferido pelo STJ no Recurso Especial $\mathrm{n}^{\circ}$ 1.784.726/SP, importante decisão na qual expressamente consignou-se que a aplicação da tese discutida segundo a qual a paternidade socioafetiva prevalece sobre a filiação biológica depende sempre do exame do caso concreto.

No terceiro capítulo, apresentam-se fundamentos doutrinários sobre a importância do contexto fático de aplicação para a compreensão das ementas, dos enunciados, das teses e demais textos legais, evitando que textos descontextualizados promovam a construção equivocada de soluções jurídicas a litígios que demandariam solução diversa.

Metodologicamente, o presente estudo funda-se em um modelo descritivo, no que diz respeito à exposição sistemática do estado da arte das filiações biológica e socioafetiva, da decisão proferida pelo STJ no julgamento do Recurso Especial $\mathrm{n}^{\circ} 1.784 .726 / \mathrm{SP}$ e dos fundamentos básicos de epistemologia e hermenêutica jurídica ${ }^{3}$ que estabelecem a moldura teórica que entendemos adequada para o endereçamento da problemática; nas considerações finais, adota-se um modelo normativo, pelo qual propõe-se a adoção de uma prática jurídica fundada na análise do contexto fático como condição sine qua non para compreensão e interpretação-aplicação dos textos normativos.

\footnotetext{
${ }^{3}$ Para fins deste estudo, entendemos epistemologia como o ramo da filosofia que tem por objetivo estudar a forma, os limites, as características e os limites da compreensão pelo sujeito cognoscente. Por hermenêutica jurídica entendemos o conjunto de princípios e técnicas utilizados na interpretação e compreensão do texto jurídico.
} 


\section{FILIAÇÃO SOCIOAFETIVA VERSUS FILIAÇÃO BIOLÓGICA}

Tradicionalmente, era na família matrimonial que derivava toda forma de paternidade e de enlaces consanguíneos e afetivos. Esta concepção de família matrimonializada, patriarcal, hierarquizada e heterossexual foi, com o passar do tempo, sendo substituída e somada a outras formas de arranjo familiar que tiveram sua legalidade reconhecida por inovações legislativas, constitucionais e infraconstitucionais, avanços doutrinárias e importantes debates travados nos tribunais superiores.

Hoje, somam-se à família matrimonial diversas classificações, dentre elas a família homoafetiva, monoparental, mosaico, substituta, eudemonista etc. As famílias deixaram de sofrer restrições em sua formatação oficial, prevalecendo os vínculos do afeto e afinidade. Tal progresso deriva de um dos princípios constitucionais aplicáveis ao Direito de Família, o princípio da pluralidade das entidades familiares, o qual aproxima-se ao reconhecimento e à efetiva proteção, pelo Estado, das múltiplas possibilidades de arranjos familiares.

Com estas novas construções do modo de constituição das famílias, surge, ao longo do tempo, relações de parentesco oriundas não só do vínculo legal e biológico, mas sim resultantes de afeto e afinidade. Dispõe o art. 1.593 do CC que o "parentesco é natural ou civil, conforme resulte de consanguinidade ou outra origem ". Desse modo, é natural o parentesco derivado de laços de sangue; quanto ao civil, recebe este nome por tratar-se de uma criação da lei, um liame jurídico existente entre os parentes originários do vínculo matrimonial ou da união estável.

Verifica-se que, explicitamente, não teve o Código Civil de 2002 tarefa de dar maiores explicações acerca da parentalidade socioafetiva (entendendo-se parentalidade como o gênero que abrange as espécies paternidade e maternidade). Porém, abre espaço para esta possibilidade decorrente da expressão "outra origem” inserida no caput do artigo supramencionado 4 .

Assim, a parentalidade socioafetiva pode ser definida como o vínculo de parentesco civil entre pessoas que não possuem entre si um vínculo biológico, porém que vivem como se fossem pais e filhos, em decorrência de forte vínculo afetivo existente entre elas. Configura-se "o critério socioafetivo de determinação do estado de filho como um tempero ao império da

\footnotetext{
4 “De qualquer sorte o Código Civil nada inovou no tocante à paridade da filiação, pois simplesmente reescreveu o mesmo texto da Carta Federal, até porque a Constituição Federal já havia estabelecido todas as bases para a completa igualdade das relações de filiação, em seguida regulamentadas pelo artigo 20 do Estatuto da Criança e do Adolescente (Lei n. 8.069/1990), cujas mudanças têm sua origem em diversos instrumentos internacionais de direitos humanos subscritos pelo Brasil, como a Declaração Universal de Direitos Humanos e a Convenção sobre os Direitos das Crianças" (MADALENO, 2020, p. 888).
} 
genética, representando uma verdadeira desbiologização da filiação, fazendo com que o vínculo paterno-filial não esteja aprisionado somente na transmissão de gens". (FARIAS; ROSENVALD, 2015, p. 611).

Os filhos socioafetivos devem ter os mesmos direitos dos biológicos, em razão da igualdade prevista na $\mathrm{CF} / 88^{5}$ (CASSETTARI, 2017, p. 25). O art. 227, §6 $6^{\circ}$, da $\mathrm{CF} / 88$, dispõe que "os filhos, havidos ou não da relação do casamento, ou por adoção, terão os mesmos direitos e qualificações, proibidas quaisquer designações discriminatórias relativas à filiação”. Outrossim, o art. 1.596 do CC estabelece que "os filhos, havidos ou não da relação de casamento, ou por adoção, terão os mesmos direitos e qualificações, proibidas quaisquer designações discriminatórias relativas à filiação"6.

Depreende-se que a parentalidade socioafetiva constitui modalidade de parentesco civil, podendo ser chamada de posse do estado de filho ${ }^{7-8}$. A posse do estado de filho manifesta a constância social da relação entre pais e filhos, tipificando uma paternidade que existe, não pelo simples fato biológico ou por força de presunção legal, mas em decorrência de elementos que estão de fato presentes, frutos de uma convivência afetiva ${ }^{9}$ (BOEIRA, 1999, p. 54). Enquanto a parentalidade socioafetiva tem origem na socioafetividade, a biológica se origina no vínculo sanguíneo. Pontes de Miranda, em seu livro intitulado "Tratado de direito de família" de 1947, dispõe que parentesco é a relação que vincula entre si pessoas que descendem umas das outras - consanguinidade - que aproxima cada um dos cônjuges dos parentes do outro (afinidade), ou que se estabelece, por fictio iuris, entre o adotado e o adotante ${ }^{10}$ (PONTES DE MIRANDA, 1947, p. 21).

\footnotetext{
${ }^{5}$ Enunciado n. 6 do Instituto Brasileiro de Direito de Família (IBDFAM): "Do reconhecimento jurídico da filiação socioafetiva decorrem todos os direitos e deveres inerentes à autoridade parental".

6 "O termo filiação apresenta um sentido plural, rico em variações e nuances, caracterizado por um verdadeiro mosaico de possibilidades, que vão desde a origem genética até a convivência cotidiana, digna do estabelecimento de uma relação firme e inabalável. São os múltiplos e variados meios de estabelecer a relação paterno-filial" (FARIAS; ROSENVALD, 2017, p. 586).

${ }^{7}$ Enunciado 256 do Conselho da Justiça Federal (CJF) - art. 1.593. "A posse do estado de filho (parentalidade socioafetiva) constitui modalidade de parentesco civil".

${ }^{8}$ Enunciado 519 do Conselho da Justiça Federal (CJF) - "O reconhecimento judicial do vínculo de parentesco em virtude de socioafetividade deve ocorrer a partir da relação entre pai(s) e filho(s), com base na posse do estado de filho, para que produza efeitos pessoais e patrimoniais".

9 "A posse de estado é a expressão mais exuberante do parentesco psicológico, da filiação afetiva. A maternidade e a paternidade biológica nada valem frente ao vínculo afetivo que se forma entre a criança e aquele que trata e cuida dela, lhe dá amor e participa de sua vida" (DIAS, 2016, p. 652).

10 "No que respeita aos filhos, a evolução dos valores da civilização ocidental levou à progressiva superação dos fatores de discriminação entre eles. Projetou-se, no campo jurídico-constitucional, a afirmação da família como grupo social fundado essencialmente nos laços da afetividade. Encontram-se na CF quatro fundamentos essenciais do princípio da afetividade, constitutivos dessa aguda evolução social da família, máxime durante as últimas décadas do século XXI: a) todos os filhos são iguais independentemente de sua origem (art. 227, § $6^{\circ}$ ); b) a adoção,
} 
A parentalidade socioafetiva apresenta um sujeito que não é o genitor por vínculos sanguíneos, mas que assume o lugar de pai ou mãe dando ao filho amor, carinho, abrigo, educação ${ }^{11}$. A função de pai ou de mãe pode, assim, ser exercida por quem não é o pai ou mãe biológico. Assim "a afetividade, como categoria jurídica, resulta da transeficácia de parte dos fatos psicossociais que a converte em fato jurídico, gerador de efeitos jurídicos" (DIAS, 2016, p. 204).

Como pontuado por Madaleno (2020, p. 889), o valor jurídico real está na condição afetiva da relação entre pai e filho e jamais na ascendência genética. Isso porque a ascendência afetiva, quando desprovida de afeto, convivência e efeitos sociais, morais e pessoais, apenas representa um efeito da natureza. Assim, a filiação socioafetiva não está lastreada no nascimento, mas sim em ato de vontade consolidada dia após dia: "socioafetiva é aquela filiação que se constrói a partir de um respeito mútuo, de um tratamento em mão-dupla como pai e filho, inabalável na certeza de que aquelas pessoas, de fato, são pai/mãe e filho" (FARIAS; ROSENVALD, 2015, p. 611).

Neste estudo, procuramos demonstrar como a abstração e descontextualização dos enunciados fez com que uma "tese" jurídica construída sobre um determinado contexto passou a ser aplicado a contextos diversos, exigindo a correção pelo Superior Tribunal de Justiça. Como pontuado por Farias e Rosenvald (2015, p. 565), inexiste norma legal que defina indubitavelmente quem será o pai, uma vez que a multiplicidade de seus conceitos abre um leque de possibilidades que impede o desenvolvimento de uma certeza inexorável.

Essas possibilidades correspondem aos diferentes critérios para determinação do estado de filho, sem que exista uma hierarquia entre eles. Desse modo, em cada caso é que se deve notar qual dos critérios prevaleceu e merece aplicação (FARIAS; ROSENVALD, 2015, p. 565). Welter mostra que as parentalidades biológica e socioafetiva devem coexistir e não uma se sobrepor à outra:

como escolha afetiva, alçou-se integralmente ao plano da igualdade de direitos (art. $227, \S \S 5^{\circ}$ e $6^{\circ}$ ); c) a comunidade formada por qualquer dos pais e seus descendentes, incluindo-se os adotivos, tem a mesma dignidade de família, constitucionalmente protegida (art. 226, § $4^{\circ}$ ); d) o direito à convivência familiar, e não a origem genética, constitui prioridade absoluta da criança e do adolescente (art. 227, caput)" (LÔBO, 2003, p. 42).

11 "Estudos diversos oriundos de outros ramos do conhecimento, em especial da Psicanálise, convergem no sentido de reconhecer que a figura do pai é funcionalizada, decorrendo de um papel construído cotidianamente - e não meramente de uma transmissão de carga genética. Ancorado nessas ideias, Rodrigo da Cunha Pereira já percebeu que o essencial para a formação de uma pessoa, para torná-la um sujeito capaz socialmente, 'é que alguém ocupe, em seu imaginário, o lugar simbólico de pai e mãe', mesmo não estabelecendo com eles, necessariamente, um vínculo biológico. Afirma-se, com isso, que na formação de uma família cada pessoa ocupa um papel, uma função, na estrutura do núcleo, e que a função paterna pode ser exercida em diferentes circunstâncias, por outra pessoa que não seja o genitor" (FARIAS; ROSENVALD, 2017, p. 610). 
[v]isto o direito de família sobre o prisma da tridimensionalidade humana, deve-se atribuir ao filho o direito fundamental às paternidades genética e socioafetiva e, em decorrência, conferir-lhe todos os efeitos jurídicos das duas paternidades. Numa só palavra, não é correto afirmar, como o faz a atual doutrina e jurisprudência do mundo ocidental, que "a paternidade socioafetiva se sobrepõe à paternidade biológica", ou que "a paternidade biológica se sobrepõe à socioafetiva", isso porque ambas as paternidades são iguais, não havendo prevalência de nenhuma delas, exatamente porque fazem parte da condição humana tridimensional, que é genética, afetiva e ontológica (WELTER, 2009, p. 222).

É sob esse plano que nos propomos a analisar as configurações da parentalidade socioafetiva no âmbito dos tribunais, principalmente a partir de um entendimento equivocadamente - em nosso sentir - difundido de que haveria uma prevalência da filiação socioafetiva sobre a filiação biológica. Haveria uma presunção de hierarquização dos tipos de parentesco, como se uma fosse superior à outra.

Tartuce critica a jurisprudência moderna, afirmando que alguns julgados estão querendo provocar uma "escolha de Sofia", ${ }^{12}$ entre os vínculos biológico e socioafetivo, que afirma não poder prosperar (TARTUCE, 2014, p. 389). Temos como exemplo o próprio acórdão reformado do Tribunal de Justiça do Estado de São Paulo, objeto do REsp n. 1.784.726/SP e análise deste estudo, o qual defendeu que a existência de paternidade socioafetiva impediria o reconhecimento da paternidade biológica. Contudo, esta prevalência, na maioria dos casos, não deve prosperar. É o que se passa a analisar nos capítulos seguintes.

\section{ANÁLISE DA DECISÃO PROFERIDA NO RECURSO ESPECIAL N. 1.784.726/SP}

Se a filiação pode decorrer de duas fontes - a biológica e a socioafetiva -, era de se esperar que houvessem hipóteses em que as duas fontes se fariam presentes, surgindo o fenômeno da multiparentalidade: a possibilidade de ser reconhecido mais de um pai ou mais de uma mãe à mesma pessoa.

O acórdão objeto do presente estudo decorre de uma ação de investigação de paternidade e retificação de registro civil movida originariamente no Estado de São Paulo. Como o processo

\footnotetext{
${ }^{12}$ A expressão "escolha de Sofia" refere-se à situação em que alguém deve tomar uma decisão difícil entre duas ou mais opções, mas qualquer decisão que seja tomada importará em grande sacrifício pessoal ou a terceiros. A expressão decorre do romance "A escolha de Sofia", do escritor norte-americano William Styron, publicado em 1979, sobre a polonesa Sofia Zawistowka, presa no campo de concentração de Auschwitz, obrigada por um oficial nazista a escolher quais de seus dois filhos seria salvo e qual deles morreria com ela em uma câmara de gás.
} 
tramita em segredo de justiça tanto na primeira quanto na segunda instâncias, todas as referências são feitas a partir dos dados obtidos no Recurso Especial n ${ }^{\circ} 1.784 .726 / \mathrm{SP}$.

Em primeira instância, exame de DNA provou a paternidade biológica pleiteada pela autora da ação, resultando na sentença de procedência que declarou a paternidade do réu. A sentença foi, entretanto, anulada em segunda instância pelo Tribunal de Justiça do Estado de São Paulo, sob o fundamento de que a ascendência genética "só produzirá efeitos jurídicos se constatada a ausência de posse de filha da autora, que tem pai registral”.

Em outras palavras, o Tribunal de Justiça do Estado de São Paulo firmou entendimento de que a parentalidade biológica somente poderia ser reconhecida se ausente a parentalidade socioafetiva, no acórdão referido como posse de estado de filho, uma vez que a autora da ação possuía pai registral. Haveria, assim, uma preponderância da parentalidade afetiva sobre a biológica: reconhecida aquela, impede-se o reconhecimento desta ${ }^{13}$.

Proposto Recurso Especial contra o acórdão proferido pelo Tribunal de Justiça de São Paulo, foi dado provimento monocrático pelo Ministro Relator Luis Felipe Salomão ${ }^{14}$, que teceu observação essencial no decorrer do seu voto, reconhecendo que a prevalência de uma paternidade à outra depende do contexto e do caso in concreto:

\begin{abstract}
A tese adotada pelo acórdão recorrido, segundo a qual a paternidade socioafetiva sempre prevalece sobre a biológica, deve ser analisada com bastante ponderação, a depender sempre do exame do caso concreto. [...] Porém, é de se notar que a prevalência da paternidade socioafetiva sobre a biológica - no mencionado precedente e em outros tantos - foi proclamada em contexto de ação negatória de paternidade ajuizada pelo pai registral, situação bem diversa da que ocorre quando o filho registral é quem busca sua paternidade biológica, sobretudo no cenário da chamada "adoção à brasileira" (BRASIL, REsp. 1.784.726/SP, Relator Ministro Luis Felipe Salomão, 2018, p. 2-3) ${ }^{15}$.
\end{abstract}

\footnotetext{
${ }^{13}$ Em sentido semelhante: "[...] II - Comungo com as correntes doutrinárias que entendem que a adoção à brasileira não pode ser desconstituída após vínculo de socioafetividade. Ao longo de vários anos, conforme afirmação da própria autora, considerou o Sr. Jose Elias como pai, ou seja, por 27 anos viveram uma perfeita relação de pai e filha e pelo simples fato de não ser o pai biológico da autora, após a morte, automaticamente o intitulou de padrasto, desconsiderando por completo a relação familiar havida entre eles. III - Não há razões nos autos que levem a justificar a nulidade do registro de nascimento. A intenção da autora é apenas de ter o nome de seu verdadeiro pai biológico em seu assento. Há de se ressaltar que o Sr. Jose Elias, por livre e espontânea vontade, demonstrou e efetivou o interesse em ter a Apelada como filha, não havendo nenhum erro ou coação para tal atitude que justifique a anulação do registro (precedente do Superior Tribunal de Justiça)" (MARANHÃ̃O, Tribunal de Justiça. Apelação Cível $n^{\circ}$ 002444. Apelantes: R. C. N. B. e outros. Apelada: S. R. B. Relatora: Nelma Celeste Souza Silva Sarney Costa. São Luís. Julgado em 22/06/2010).

${ }^{14}$ A decisão monocrática foi confirmada posteriormente em 7 de maio de 2019, em sede do julgamento de Agravo Interno, tendo participado do julgamento, além do Ministro Relator, os Ministros Raul Araújo, Maria Isabel Gallotti, Antônio Carlos Ferreira e Marco Buzzi.

${ }^{15}$ A decisão monocrática restou assim ementada: "CIVIL. DIREITO DE FAMÍLIA. RECURSO ESPECIAL. AÇÃO INVESTIGATÓRIA DE PATERNIDADE AJUIZADA PELA FILHA. 1. A tese segundo a qual a paternidade socioafetiva sempre prevalece sobre a biológica deve ser analisada com bastante ponderação, a
} 
Não é possível falar - de forma teórica e abstrata - da prevalência da filiação socioafetiva sobre a filiação biológica ou vice-versa: a prevalência de uma sobre a outra ou a possibilidade de multiparentalidade decorre do caso concreto. O sentido da norma a ser concluída ao caso concreto depende, portanto, do contexto de aplicação ${ }^{16}$.

A "tese" segundo a qual haveria prevalência da paternidade socioafetiva sobre a biológica somente é aplicada no contexto da ação negatória de paternidade, quando o pai registral ou socioafetivo busca desfazer-se do vínculo de paternidade, pleiteando o exame de DNA para provar que não é o pai. O exame de DNA, neste caso, não tem o condão de desfazer o vínculo de paternidade, pois esta não decorreu da fonte biológica, mas sim da socioafetividade.

Não se pode, todavia, transportar esta norma, construída para ser aplicada no contexto da ação negatória de paternidade, para outros contextos diversos, como, v. g., na ação de investigação de paternidade na qual o filho pretende para ver declarada sua filiação com o pai biológico ${ }^{17}$.

Deve-se ter claro que as duas fontes da parentalidade - biológica e socioafetiva - não se confundem e não são necessariamente excludentes. Na ação negatória de paternidade, v. g., na qual o pai registral voluntariamente reconheceu como seu filho não biológico, de nada lhe

depender sempre do exame do caso concreto. É que, em diversos precedentes desta Corte, a prevalência da paternidade socioafetiva sobre a biológica foi proclamada em contexto de ação negatória de paternidade ajuizada pelo pai registral(ou por terceiros), situação bem diversa da que ocorre quando o filho registral é quem busca a paternidade biológica, sobretudo no cenário da chamada "adoção à brasileira". 2. De fato, é de prevalecer a paternidade socioafetiva sobre a biológica para garantir direitos aos filhos, na esteira do princípio do melhor interesse da prole, sem que, necessariamente, a assertiva seja verdadeira quando é o filho que busca a paternidade biológica em detrimento da socioafetiva. No caso de ser o filho - o maior interessado na manutenção do vínculo civil resultante do liame socioafetivo - quem vindica estado contrário ao que consta no registro civil, socorre-lhe a existência de "erro ou falsidade" (art. 1.604 do CC/02) para os quais não contribuiu. Afastar a possibilidade de o filho pleitear o reconhecimento da paternidade biológica, no caso de "adoção à brasileira", significa impor-lhe que se conforme com essa situação criada à sua revelia e à margem da lei. 3. A paternidade biológica gera, necessariamente, responsabilidade não evanescente e que não se desfaz com a prática ilícita da chamada "adoção à brasileira", independentemente da nobreza dos desígnios que a motivaram. E, do mesmo modo, a filiação socioafetiva desenvolvida com os pais registrais não afasta os direitos da filha resultantes da filiação biológica. 4 . Recurso especial provido” (BRASIL, REsp. 1.784.726/SP, Relator Ministro Luis Felipe Salomão, 2018, p. 2-3). 16 “É julgamento que enfrenta duas questões claramente diversas, pois, de um lado atribui efeitos jurídicos à filiação socioafetiva, que sem assento em texto de lei, dependia das diferentes interpretações jurisprudenciais, que por vezes acolhiam a sobreposição da filiação socioafetiva, a qual se tornava irreversível quando o adotante à brasileira pretendesse desconstituí-la, e noutras vezes, sob o ponto de vista dos interesses do filho de complacência faziam prevalecer os vínculos biológicos sobre o elo socioafetivo, mesmo quando presente uma forte e estável filiação socioafetiva" (MADALENO, 2020, p. 911).

17 "Porém, é de se notar que a prevalência da paternidade socioafetiva sobre a biológica - no mencionado precedente e em outros tantos - foi proclamada em contexto de ação negatória de paternidade ajuizada pelo pai registral, situação bem diversa da que ocorre quando o filho registral é quem busca sua paternidade biológica, sobretudo no cenário da chamada 'adoção à brasileira"” (BRASIL, REsp. 1.784.726/SP, Relator Ministro Luis Felipe Salomão, 2018, p. 2-3). 
adianta negar a ausência de vínculo biológico, pois a fonte de sua paternidade é outra: a socioafetividade. Ao contrário, na ação de investigação de paternidade com fundamento no vínculo biológico, a existência de paternidade socioafetiva registrada (pai registral) não impede o reconhecimento da paternidade biológica: as duas fontes não se confundem e não se excluem.

A fim de elucidar a importância do contexto de aplicação, tendo como referência o REsp. 1.784.726/SP, procuramos sistematizar e apresentar algumas características das ações negatória e de investigação de paternidade:

QUADRO 1: Características das ações negatória e de investigação de paternidade

\begin{tabular}{|l|l|}
\hline \multicolumn{1}{|c|}{$\begin{array}{c}\text { AÇÃO NEGATÓRIA DE } \\
\text { PATERNIDADE }\end{array}$} & \multicolumn{1}{|c|}{$\begin{array}{c}\text { AÇÃO DE INVESTIGAÇÃO DE } \\
\text { PATERNIDADE }\end{array}$} \\
\hline $\begin{array}{l}\text { O pai registral ou socioafetivo busca } \\
\text { desfazer-se do vínculo de paternidade. O pai } \\
\text { registral busca o desfazimento da paternidade } \\
\text { socioafetiva e invoca, para tanto, a ausência } \\
\text { da fonte biológica. }\end{array}$ & $\begin{array}{l}\text { O filho busca o reconhecimento de sua } \\
\text { filiação biológica (sem, necessariamente, } \\
\text { A existência de pai registral-paternidade } \\
\text { socioafetiva não desfaz os vínculos } \\
\text { biológicos e não impede o reconhecimento da } \\
\text { paternidade oriunda desta fonte }{ }^{18} \text {. }\end{array}$ \\
\hline $\begin{array}{l}\text { A filiação-paternidade socioafetiva já está } \\
\text { constituída. Não se pode desfazê-la em } \\
\text { prejuízo do filho e do dispositivo } \\
\text { constitucional da paternidade responsável. }\end{array}$ & $\begin{array}{l}\text { O filho busca o reconhecimento de sua } \\
\text { filiação biológica que é igualmente } \\
\text { protegida, constituindo-se em fator de } \\
\text { concretização do princípio da dignidade da } \\
\text { pessoa humana. }\end{array}$ \\
\hline $\begin{array}{l}\text { Aquele que registrou seu filho sabendo que } \\
\text { não era pai biológico não pode pleitear } \\
\text { "estado contrário ao que resulta do registro de } \\
\text { nascimento" (CC, art. 1.604), pois aquele que }\end{array}$ & $\begin{array}{l}\text { Mesmo possuindo pai registral, o filho pode } \\
\text { se valer da parte final do art. 1.604 do CC: }\end{array}$ \\
\hline
\end{tabular}

18 'Porém, a chamada 'adoção à brasileira' - ao contrário da adoção legal - não tem aptidão de romper os vínculos civis entre o filho e pai biológicos, que devem ser restabelecidos sempre que o filho manifestar o seu desejo de desfazer o liame jurídico nascido do registro ilegalmente levado a efeito, restaurando-se, por conseguinte, todos os consectários legais resultantes da paternidade biológica, como os registrais, patrimoniais e hereditários" (BRASIL, REsp. 1.784.726/SP, Relator Ministro Luis Felipe Salomão, 2018, p. 3). 
deu causa à invalidade não pode se beneficiar "salvo provando-se erro ou falsidade do de sua própria torpeza em prejuízo do filho ${ }^{19}$. registro" $^{20}$.

Fonte: Autoria própria.

Como demonstrado no quadro acima, os contextos que fundamentam a ação negatória de paternidade e a ação investigatória de paternidade são substancialmente diferentes a ponto de alterar a solução normativa a ser conferida a cada caso.

$\mathrm{Na}$ ação de investigação de paternidade, o filho busca a declaração de sua filiação biológica, direito da personalidade que concretiza o princípio da dignidade da pessoa humana. A paternidade socioafetiva (registral ou não), poderá ou não ser mantida, de acordo com o caso concreto e o pedido formulado pelo autor: a retificação do registro civil pode se constituir em mera adição do nome do pai biológico ou também em exclusão do nome do pai socioafetivo.

Por outro lado, quando o pai registral ajuíza ação negatória de paternidade, a fim de se abster das responsabilidades inerentes do estado de filiação e da paternidade socioafetiva - ou por qualquer outro motivo - pode-se dizer que esta paternidade prevalece sobre a biológica, mas apenas no sentido de que a filiação decorrente do reconhecimento registral e do qual decorreu a filiação socioafetiva não pode ser negada devido à falta de vínculo biológico. A paternidade socioafetiva é justamente aquela que não exige vínculo biológico. A alegação de ausência de vínculo biológico, portanto, de nada serve para desconstituir o vínculo de filiação socioafetivo $^{21}$.

\footnotetext{
19 "Havendo paternidade socioafetiva coincidente com a registral, impede-se seja vindicado "estado contrário ao que resulta do registro de nascimento", mesmo em caso de "falsidade do registro" (art. 1.604 do CC/02), para que aquele que deu causa à invalidade não se beneficie da própria torpeza em prejuízo ao interesse do filho, que em nada contribuiu para a situação" (BRASIL, REsp. 1.784.726/SP, Relator Ministro Luis Felipe Salomão, 2018, p. $3)$.

20 "Porém, no caso de ser o filho - o maior interessado na manutenção do vínculo civil resultante do liame socioafetivo - quem vindica esse estado contrário ao que consta no registro civil, parece claro que lhe socorre a existência de 'erro ou falsidade' para os quais não contribuiu. Afastar a possibilidade de o filho pleitear o reconhecimento da paternidade biológica, no caso de 'adoção à brasileira', significa impor-lhe que se conforme com essa situação criada à sua revelia e à margem da lei" (BRASIL, REsp. 1.784.726/SP, Relator Ministro Luis Felipe Salomão, 2018, p. 3).

${ }^{21}$ No âmbito dos tribunais estaduais, entendimento semelhante ao exposto no texto: "Apelação cível. Ação negatória de paternidade. Justiça gratuita deferida. Desconstituição da filiação pela nulidade do assento de nascimento. Reconhecimento espontâneo e consciente da paternidade. Vício de consentimento inexistente. Realização de teste de paternidade por análise de DNA. Exclusão da paternidade biológica. Irrelevância. Existência de sólido vínculo afetivo por mais de 23 anos. Filiação socioafetiva demonstrada. Desconstituição da paternidade vedada. Recurso parcialmente provido. É irrevogável e irretratável a paternidade espontaneamente reconhecida por aquele que tinha plena consciência de que poderia não ser o pai biológico da criança, mormente quando não comprova, estreme de dúvidas, vício de consentimento capaz de macular a vontade no momento da lavratura do assento de nascimento. A filiação socioafetiva, fundada na posse do estado de filho e consolidada no afeto e na
} 
Para que o pai registral obtenha êxito na ação negatória de paternidade, segundo o Ministro Luis Felipe Salomão, seria necessária a demonstração, "a um só tempo, da inexistência de origem biológica, e também de que não tenha sido constituído o estado de filiação, fortemente marcado pelas relações socioafetivas e edificado na convivência familiar" (BRASIL, REsp. 1.784.726/SP, Relator Ministro Luis Felipe Salomão, 2018, p. 5).

Com razão o Ministro, pois, neste caso, seria desconstituída a paternidade não devido à inexistência de vínculo biológico, mas porque não houve a formação do vínculo de paternidade socioafetiva. Somente a constituição de relações socioafetivas paterno-filiais na convivência familiar é que gera a paternidade socioafetiva e, portanto, sua inexistência gera a inexistência desta última.

O Ministro Luis Felipe Salomão, em sua decisão monocrática, citou o precedente firmado no julgamento do REsp 833.712/RS, com julgamento datado de 17 de maio de 2007, de relatoria da Ministra Nancy Andrighi. Nele, discutiu-se a controvérsia sobre qual a paternidade/maternidade que deve prevalecer quando conflitantes: a biológica ou a socioafetiva. Da análise deste precedente, conclui-se que não há que se falar em preponderância entre a parentalidade socioafetiva sobre a biológica, pois a solução normativa dependerá das peculiaridades do caso concreto.

O REsp 833.712/RS teve por objeto acórdão proferido pelo Tribunal de Justiça do Rio Grande do Sul que afirmou: "verdade socioafetiva que prevalece sobre a verdade genética". O Recurso Especial foi provido e reformou o acórdão do tribunal gaúcho e, em seu voto, a Ministra Nancy Andrigui teceu críticas expressas à existência de uma "tese" de preponderância da parentalidade socioafetiva sobre a biológica:

\footnotetext{
Consideradas as peculiaridades do processo, tem-se que a aludida tese da caracterização, pelo Tribunal de origem, de vínculo sócio-afetivo decorrente de "adoção à brasileira", que, em concorrência direta com o reconhecido vínculo biológico, teria o condão de a este se sobrepor, deve ser objeto de acurada reflexão. [...] Em conclusão, releva ponderar que, nas questões em que presente a dissociação entre os vínculos familiares biológico e sócio-afetivo, nas quais seja o Poder Judiciário chamado a se posicionar, deve o julgador, ao decidir, atentar de forma acurada para as peculiaridades do processo, cujos desdobramentos devem pautar as decisões (BRASIL, Superior Tribunal de Justiça, REsp 833.712/RS, relatora Ministra Nancy Andrigui, 2007, p. 9-10).
}

convivência familiar, prevalece sobre a verdade biológica" (SANTA CATARINA, Tribunal de Justiça. Apelação Cível $n^{o}$ 005050-4. Apelante: A. B. O. Apelado: G. M. O. e outros. Relator: Fernando Carioni. Lages. Julgado em 26/04/2011). 
O problema, segundo pensamos, reside justamente na existência de uma "tese" sobre o assunto. O sistema de precedentes judiciais "à brasileira", se é que podemos chamá-lo de sistema de precedentes judiciais, vem sendo construído sobre um conjunto de teses-enunciados, e não sobre casos concretos que permitam a compreensão do precedente a identificação do conjunto fático cuja semelhança a outros casos permitiria conferir solução normativa igual à que foi construída no precedente.

Podemos verificar essa problemática na discussão travada entre os Ministros do Supremo Tribunal Federal no Recurso Extraordinário $n^{\circ}$ 898.060, julgamento no qual a Corte Suprema "fixou a tese" da possibilidade de pluriparentalidade. A fixação de "teses" decorre da tendência de objetivação do recurso extraordinário, pelo qual se constrói soluções jurídicas "em abstrato" para posteriormente serem aplicadas ao caso concreto. Este é apenas um pretexto para permitir ao STF a construção da tese ${ }^{22}$.

Primeiro, o Ministro Luiz Fux, reconhecendo que a metodologia de objetivação do recurso extraordinário faz surgir uma decisão constituída de duas partes: uma objetiva (a construção da "tese"), e outra subjetiva (na qual se aplica a tese ao caso concreto):

\begin{abstract}
Eu citaria aqui talvez duas dezenas de casos em que, em repercussão geral, fixa-se uma tese levando-se em consideração o processo subjetivo [sic] e, depois, decide-se o caso concreto. Quantas vezes aqui nós já decidimos, até em matéria penal, desfavoravelmente ao réu, mas, no habeas corpus, concedemos. Isso faz parte dessa nova metodologia de objetivação do recurso extraordinário. Há uma parte objetiva e uma parte subjetiva. Todos os acórdãos mencionam isso; há uma tese, que é a tese que tinha de ser enfrentada, e a solução do caso concreto. Então, com a devida vênia, essa premissa não me impressiona (BRASIL, Recurso Extraordinário nº 898.060/SC, relator Ministro Luiz Fux, 2016, p. 3).
\end{abstract}

A construção da "tese" acaba por extrapolar o que seria necessário para o julgamento do caso concreto. Esta possibilidade decorreria da própria objetivação do recurso extraordinário, medida de racionalização para evitar que se tenha novos casos a toda hora. Para tanto, é necessário que se considere o caso concreto em um "sentido ampliado". Confira-se, nas palavras do Ministro Gilmar Mendes:

O que o Relator propõe, a partir do caso da repercussão geral, é fazer um construto que dê resposta. Entendo a posição quanto à parte dispositiva; mas, a mim, parece-me que devemos ter essa apreensão, sob pena de termos, a toda hora, novos casos. Quer dizer, o propósito aqui é de uma racionalização. Não se trata de nada abusivo. Há um dado do qual não se pode fugir. Acho que isso o CPC novo reforçou: a rigor, a

22 Nas palavras do Ministro Gilmar Mendes: “[...] até vou usar uma expressão que nossos amigos portugueses utilizam, referindo-se ao sistema americano de controle incidental: judicial review -, o tal case é um pretexto para que se discuta o tema" (BRASIL, Recurso Extraordinário nº 898.060/SC, relator Ministro Luiz Fux, 2016, p. 4). 
objetivação do recurso extraordinário, gostemos ou não. Então, acho que esse é um debate importante - e até agradeço a menção que Sua Excelência fez - para que se possa assentar. Não podemos ficar restritos apenas ao caso em sua forma dogmática, temos de vê-lo nesse sentido ampliado (BRASIL, Recurso Extraordinário $\mathrm{n}^{\mathrm{o}}$ 898.060/SC, relator Ministro Luiz Fux, 2016, p. 4-5).

A objetivação do recurso extraordinário e a construção de teses visa a conferir maior racionalização ao sistema de distribuição de justiça brasileira. Mas essa metodologia de julgamento de recursos não reflete a prática de um sistema de precedentes judiciais e não se alinha aos desenvolvimentos havidos desde o giro linguístico em matéria hermenêutica. No afã de se julgar casos iguais de maneira igual, a construção e teses e enunciados reproduz os mesmos problemas dos enunciados do texto legal: abstração, descontextualização e a possibilidade de a tese ou enunciado receba interpretações diferentes.

\section{VAGUEZA E DESCONTEXTUALIZAÇÃO DAS TESES, DOS ENUNCIADOS, DAS EMENTAS E DAS SÚMULAS}

No capítulo anterior, vimos que o Superior Tribunal de Justiça deu provimento a dois recursos especiais para o fim de anular/reformar acórdãos proferidos por tribunais estaduais que haviam aplicado a "tese" de que a paternidade socioafetiva prevalece sobre a paternidade biológica. Segundo nossa hipótese de trabalho, estas "teses", quando não construídas expressamente pelos tribunais superiores no âmbito da objetivação dos recursos extraordinários lato sensu, decorre da análise e aplicação de ementas e enunciados descontextualizados dos casos de origem.

As teses, os enunciados, as ementas, as súmulas (doravante todos chamados meramente de "enunciados"), possuem o mesmo problema do texto legal: são descontextualizados e permitem, por isso mesmo, intepretações diferentes. Ao permitir interpretações diferentes, permitem que casos diferentes sejam julgados de forma igual, problema oposto ao conhecido problema do Direito brasileiro de se construir soluções jurídicas diferentes para casos iguais. É o que acontece com a tese que se propagou pelos escaninhos do Direito brasileiro de que "a paternidade socioafetiva prevalece sobre a paternidade biológica”. Descontextualizada, passou a ser aplicada a casos diferentes que demandavam soluções jurídicas diferentes.

A dificuldade paira nos enunciados porque não se pode identificar quais são os motivos determinantes da decisão, se eles condizem com o que foi decidido, com os posicionamentos dos ministros no desenrolar do julgamento e se apresentam a mesma similitude jurídica com os precedentes judiciais que embasaram a decisão. É na abstratividade dos enunciados que há a 
resolução de casos diferentes pela mesma solução jurídica. A falta de um contexto de aplicação permite a solução de casos diferentes pela mesma norma, bem como a solução de casos iguais de formas distintas.

Para tanto, deve-se analisar quais os problemas oriundos dos enunciados e como eles desencadeiam uma série de inconsistências em torno das decisões posteriores que se basearam nele. Os enunciados ocultam a singularidade dos casos e a situação concreta. Uma pauta geral aplicada de maneira objetiva induz o ofuscamento da singularidade do caso concreto $^{23}$ (STRECK, 2008, p. 171). Passou-se, com isso, a utilizar os enunciados como os elementos centrais fundamentais da decisão, sem que houvesse maior apuro na verificação se o caso sob julgamento seria juridicamente semelhante ao caso-precedente sobre o qual foi firmado o enunciado:

É preciso entender que um dos motivos da fragmentação do direito brasileiro é o descolamento - historicamente efetuado - entre o contexto de cada caso, que aqui, mutatis mutandis, poderíamos chamar de tragenden Gründe, e aquilo que foi sendo forjado como a ementa do julgamento. As ementas, na medida em que utilizadas sem contexto, foram contribuindo para uma espécie de "relaxamento da obrigação de fundamentação". Não se trata de aproximar ou mixar a civil law com a common law, mas, antes disso, de se construir possibilidades de o direito efetivamente ser o produto de uma cadeia coerente e íntegra daquilo que compõe a normatividade da comunidade política (STRECK, 2018, p. 396).

Tem-se apenas uma exposição da "jurisprudência" sem uma preocupação técnicoprocessual. São citadas ementas de julgados anteriores sem que se resulte a uma comparação exaustiva entre os casos; ou então uma repetição de súmulas sem que, de igual modo, os casos que lhe deram origem sejam levados em consideração ${ }^{24}$. De igual modo, tamanha preocupação é com os enunciados das súmulas ${ }^{25}$. Na cultura brasileira, os tribunais acabaram aplicando a súmula como se mandamentos fossem, com caráter genérico, sem darem atenção aos casos

\footnotetext{
23 “É nesse exato sentido a lição de Gadamer, comentando a atualidade hermenêutica da filosofia prática aristotélica: um saber geral que não saiba aplicar-se à situação concreta permanece sem sentido e até ameaça obscurecer as exigências concretas que emanam de uma determinada situação" (STRECK, 2008, p. 171).

24 "O que se tem visto, geralmente, é a repetição de velhas fórmulas ou apenas uma descrição da jurisprudência sem uma preocupação técnico-processual - é dizer, são citadas ementas de julgados anteriores sem que se proceda a uma comparação exaustiva entre os casos (presente e passado) ou então uma repetição de súmulas sem que, de igual modo, os casos que the deram origem sejam levados em consideração -, bem como sem considerar as suas implicações constitucionais, num regime político-democrático" (BAHIA, 2016, p. 42).

25 "Súmula é um resumo, uma resenha, um relatório. A Súmula da Jurisprudência Predominante é um resumo da jurisprudência do Tribunal, onde são incluídos enunciados que apresentam o entendimento consolidado sobre determinada questão jurídica. Em síntese, trata-se de um compêndio de rationes decidendi resumidas e estruturadas administrativamente pelo próprio tribunal que as produziu" (LUCCA, 2015, p. 311).
} 
concretos que lhes deram origem ou com a regra individual neles determinada: a ratio decidendi ${ }^{26}$ (ZANETI JR., 2015, p. 192-193):

[t]rata-se aqui do fenômeno da recepção frustrada pela cultura local. Queriam os ministros do STF criar um sistema de precedentes, mas criaram um sistema de centralização e unificação dos direitos a partir dos tribunais superiores, ao estilo do que já havia ocorrido no passado em Portugal com os assentos e na Europa com as diversas formas de jurisprudência vinculante documentadas pela doutrina, jurisprudência com caráter geral e abstrato (ZANETI JR, 2015, p. 192-193).

Como explicita Streck (2018, p. 359), as súmulas no Brasil não funcionam de maneira a facilitar a aplicação dos precedentes judiciais. Isso porque não parece ser possível, hermeneuticamente, o controle prévio de abrangência de situações concretas. Somente o exame do caso concreto, com a análise da ratio decidendi e até mesmo do obter dicta é que permite a uma resposta adequada de bom emprego não somente de uma súmula, como de qualquer texto legal ${ }^{27}$.

Hermeneuticamente, "não tem sentido falar em vinculação de conceitos jurídicos ou vinculação de ementas jurisprudenciais. Queiramos ou não, é isso o que tem sido feito: vinculação de vulgatas de pandectas, em uma tosca imitatio da jurisprudência dos conceitos" (STRECK, 2018, p. 389). Desse modo, as súmulas e ementas não podem ser entendidas como enunciados claros e inequívocos, isso porque, infelizmente, a prática judiciária brasileira não lhes dá a devida importância em um sistema de aplicação de precedentes judiciais. São enunciados descontextualizados, que impedem a compreensão da ratio decidendi e a possibilidade-necessidade de se realizar a distinção dos casos. Além do mais, nas suas elaborações, muitas vezes, são confundidos os motivos determinantes com o obiter dictum da decisão.

O enunciado segundo o qual "a paternidade socioafetiva prevalece sobre a paternidade biológica" somente pode ser entendido a partir do contexto para o qual foi construído: a ação negatória de paternidade, promovida por aquele que voluntariamente declarou como seu o filho com o qual não possui laços biológicos (a chamada "adoção à brasileira"). Quando desconectada deste contexto, passou a ser aplicada como solução jurídica em ações

\footnotetext{
${ }^{26}$ Ratio decidendi é a parte da fundamentação de um precedente que vincula os demais julgadores, é dizer, que possui autoridade e deve ser aplicada em futuros casos semelhantes; ao contrário, obiter dictum é a parte da fundamentação do precedente que não é vinculante, possui apenas função complementar ou expletiva.

27 “A formação de significados de significantes depende de um existencial que é a temporalidade. Por isso, o tempo é o nome do ser, dirá Heidegger. Isso exige dizer: assim como qualquer enunciado não possui 'vida própria', o 'precedente' não cabe na súmula". (STRECK, 2018, p. 359).
} 
investigatórias de paternidade (no capítulo anterior, vimos isso acontecer nos acórdãos proferidos pelo Tribunal de Justiça de São Paulo e do Rio Grande do Sul, posteriormente reformados pelo Superior Tribunal de Justiça).

A metodologia de aplicação dos enunciados prejudica toda a cadeia de aplicação de precedentes de um tribunal e a consistência e integridade das decisões. Infelizmente, nos tribunais brasileiros, não há ainda uma técnica que garanta, com efetividade, a transmissão de todo arcabouço e complexo julgado. Parece, como pontua Streck (2018, p. 395-396), indispensável a tarefa de reconstrução narrativa da cadeia de decisões passadas, visando reintegrar um ideal de coerência e integridade normativas, no que a problemática se aproxima de Dworkin e daquilo que, em Verdade e Consenso, trabalha como "resposta adequada a Constituição".

\section{CONCLUSÃO}

O texto da lei é, essencialmente, abstrato. Seu sentido decorre da interpretação dada pelo intérprete. Das diversas interpretações passíveis de serem dadas ao texto legal abstrato decorre o fenômeno jurídico de se julgar casos iguais de maneira diferente a partir do mesmo fundamento legal.

$\mathrm{Na}$ tentativa de racionalizar o sistema de distribuição de justiça, adotou-se uma metodologia de criação de súmulas, enunciados e teses que visam a julgar os casos iguais de maneira semelhante. Ocorre que as súmulas, os enunciados e as teses possuem as mesmas características do texto legal: a abstração e a descontextualização. Possuindo as mesmas características, acabaremos alcançando o mesmo resultado: o texto das súmulas, dos enunciados e das teses podem ser interpretados de forma diferente, gerando resultado com sinal oposto àquele que se combate, i. e., casos diferentes passam a ser julgados de forma igual.

É o que procuramos demonstrar neste estudo com a tese segundo a qual "a filiação socioafetiva tem preponderância sobre a filiação biológica": onde existe aquela, esta não pode ser reconhecida. A tese, entretanto, foi construída sobre um determinado contexto: a ação negatória de paternidade, movida por quem voluntariamente declarou-se como pai de alguém com o qual não possuía ascendência biológica (prática conhecida como "adoção à brasileira"). Construída voluntariamente a relação paterno-filial, esta não pode ser desconstituída sob a alegação de falta de vínculo biológico, preponderando, in casu, a paternidade socioafetiva sobre a ausência de ascendência biológica. 
Esta solução jurídica não pode ser transportada para contextos diversos, como a ação investigatória de paternidade. Nesta, o reconhecimento da paternidade biológica não pode ser impedido devido à existência de paternidade socioafetiva. Ambas podem conviver, gerando o fenômeno da multiparentalidade, pois decorrem de fontes diferentes: o vínculo biológico e o vínculo afetivo.

Contextos diferentes demandam a construção de soluções jurídicas diferentes. A transposição indevida de uma "tese" jurídica criada em um contexto e aplicada em outro contexto diferente decorre de sua abstração e descontextualização. Interpretada sem análise do contexto fático que lhe deu origem, a "tese" (bem como os enunciados, súmulas e ementas) passa a ser aplicada em contextos diferentes.

Ao se criar metodologias que visam racionalizar a aplicação do Direito, evitando que casos iguais sejam julgados de forma diferente, adotou-se uma sistemática que levou o sistema de distribuição de justiça a um resultado oposto: casos diferentes sendo julgados de forma igual. Esse sistema de precedentes "à brasileira" não ataca os fundamentos que originou o problema que se pretendia corrigir: adotou-se a mesma prática de interpretação do enunciado, da tese, da súmula e da ementa como se fosse um texto de lei, um ente que conteria em si seu próprio significado independentemente do contexto do qual extrai sem sentido.

Nesse sentido, o Superior Tribunal de Justiça corrigiu dois acórdãos proferidos pelos Tribunais de Justiça dos Estados de São Paulo e Rio Grande do Sul, de modo a fazer prevalecer a necessidade de análise do contexto fático para a construção da solução normativa adequada ao caso concreto.

\section{REFERÊNCIAS BIBLIOGRÁFICAS}

BRASIL. Código Civil. Brasília: Senado Federal, 2002.

BRASIL. Constituição da República Federativa do Brasil. Brasília: Senado Federal, 1988.

BRASIL, Superior Tribunal de Justiça. Agravo Interno nos Embargos de Declaração no Recurso Especial 1.784.726/SP. Quarta Turma. Relator Ministro Luis Felipe Salomão. Diário da Justiça da União Eletrônico. Julgado em 07/05/2019.

BRASIL, Superior Tribunal de Justiça. Recurso Especial 833.712/RS. Terceira Turma. Relatora Ministra Nancy Andrighi. Diário da Justiça da União Eletrônico. Julgado em 17/05/2007. 
BRASIL, Supremo Tribunal Federal. Tema 622: A paternidade socioafetiva, declarada ou não em registro público, não impede o reconhecimento do vínculo de filiação concomitante baseado na origem biológica, com os efeitos jurídicos próprios. Leading case: Recurso Extraordinário 898.060/SC. Plenário. Relator Ministro Luiz Fux. Diário da Justiça da União Eletrônico. Julgado em 21/09/2016.

BAHIA, Alexandre Gustavo Melo Franco. Recursos Extraordinários no STF e no STJ. 2. ed. Curitiba: Juruá, 2016.

BOEIRA, José Bernardo Ramos. Investigação de paternidade: posse de estado de filho: paternidade socioafetiva. Porto Alegre: Livraria do Advogado, 1999.

CASSETTARI, Christiano. Multiparentalidade e parentalidade socioafetiva: efeitos jurídicos. 3. ed. rev., atual. e ampl. São Paulo: Atlas, 2017.

DIAS, Maria Berenice. Manual de direito das famílias [livro eletrônico]. 4. ed. São Paulo: Revista dos Tribunais, 2016.

FARIAS, Cristiano Chaves de; ROSENVALD, Nelson. Curso de direito civil: famílias. 7 ed. rev. ampl. e atual. São Paulo: Atlas, 2015. v. 6.

LÔBO, Paulo Luiz Netto. In: AZEVEDO, Álvaro Villaça (coord.). Código Civil Comentado. São Paulo: Atlas, 2003. v. XXVI.

LUCCA, Rodrigo Ramina. O dever de motivação das decisões judiciais. Salvador: Juspodivm, 2015.

MADALENO, Rolf. Direito de Família. 10 ed. Rio de Janeiro: Forense, 2020.

MARANHÃO, Tribunal de Justiça. Apelação Cível no 002444. Apelantes: R. C. N. B. e outros. Apelada: S. R. B. Relatora: Nelma Celeste Souza Silva Sarney Costa. São Luís. Julgado em 22/06/2010.

PONTES DE MIRANDA, Francisco Cavalcanti. Tratado de direito de família. 3. ed. São Paulo: Max Limonad, 1947. v. III.

SANTA CATARINA, Tribunal de Justiça. Apelação Cível no 005050-4. Apelante: A. B. O. Apelado: G. M. O. e outros. Relator: Fernando Carioni. Lages. Julgado em 26/04/2011.

STRECK, Lênio Luiz. Jurisdição constitucional. 5. ed. Rio de Janeiro: Forense, 2018.

STRECK, Lênio Luiz. Súmulas, vaguezas e ambiguidades: necessitamos de uma "teoria geral dos precedentes"? Revista Direitos Fundamentais e Justiça, n. 5, out./dez. 2008.

TARTUCE, Flávio. Direito civil: direito de família. 9. ed. São Paulo: Método, 2014. 
WELTER, Belmiro Pedro. Teoria tridimensional do direito de família. Porto Alegre: Livraria do Advogado, 2009. p. 222.

ZANETI JR, Hermes. O valor vinculante dos precedentes. Salvador: JusPodium, 2015.

\section{DADOS DA PUBLICAÇÃO}

Categoria: artigo submetido ao double-blind review.

Recebido em: 20/10/2020. Aceito em: 12/07/2021. 